\title{
Ensino-aprendizagem da Lingua Inglesa como Lingua Estrangeira: refletir para transformar, de Magali Rosa de Sant'Anna
}

\author{
Sáo Paulo: BT Acadêmica, 2014
}

\author{
Glauco Corrêa da Cruz Bacic Fratric \\ Doutor em Letras. Professor dos cursos de graduação em Letras-Inglês e em Tradutor e Intérprete da \\ Universidade Nove de Julho. \\ fratric@unig.pro.br
}

Ensinar línguas estrangeiras tem sido, no decorrer da história, tarefa das mais desafiadoras, campo fecundo para pesquisas em diversas vertentes. Seja por aspectos político-econômicos, profissionais, culturais ou por lazer, a humanidade necessita aprender uma língua estrangeira (LE). Fato é que a língua inglesa (LI) começou a ganhar status de International Language of Communication gradativamente, a partir da segunda metade do século XX. Como resultado, um número grande de profissionais de ensino da LI como LE adentraram as escolas, sejam elas específicas para o aprendizado de idiomas, ou sejam elas do ensino regular.

Em um momento presente dinâmico, no qual as mudanças ocorrem em alta velocidade, a autora Magali Rosa de Sant'Anna, na obra EnsinoAprendizagem da Lingua Inglesa como Lingua Estrangeira: refletir para transformar, nos provoca a refletir de imediato sobre o ofício de ensinar LI em cenário de constantes transformações.

Seus escritos propóem-se a estimular professores e pesquisadores de LI à reflexão, não somente a partir de seu título, mas também da epígrafe, em cuja citação do educador Paulo Freire conclui-se que "ninguém ignora tudo. Ninguém sabe tudo. Todos nós sabemos alguma coisa. Todos nós ignoramos alguma coisa. Por isso aprendemos sempre." A partir daí, poderemos aos poucos delinear o que virá nas páginas subsequentes, ou seja, um diálogo reflexivo entre autora e leitor no qual não se buscam verdades eternizadas e, sim, a construção de um saber, de um conhecimento conjunto, de um compartilhamento de experiências, como reflexo desse diálogo.

Em sua esquematização de capítulos e de subtemas, delimitada minuciosamente, reconhecemos as fases centrais, ou subdivisões desse diá- 
logo entre autora e leitor: uma conversa, na qual se trazem à tona alguns princípios e conceitos que norteiam o aprendizado de línguas, dispondo ao leitor toda uma vasta gama terminológica, que mapeia as partes envolvidas no universo ensino-aprendizagem. Percebem-se algumas diferenças essenciais na compreensão do que venham a ser aquisição e aprendizagem, bem como de que forma esses processos se fazem presentes no desenvolvimento do falante da língua materna (LM), no da LE e no da segunda língua (SL).

Feita a distinção entre aquisição e aprendizagem, adentra-se um universo prático, detalhado, das dificuldades relacionadas ao aprendizado de LI que não se restringem apenas a objetos gramaticais e de estrutura sintática, mas também contemplam questóes de oralidade, ou de speaking, com foco em fonologia e pronúncia, culminando, entre vários outros aspectos, com os famosos 'trava-línguas', e com algumas dicas de como os exercitar.

Uma outra abordagem se dá quanto ao vocabulário e à fluência. No primeiro, a autora dedica seus estudos a uma categoria verbal proveniente das línguas escandinavas, no início da idade média, que para aprendizes de LM neolatina como a nossa (o português), se destaca como um dos maiores desafios na aprendizagem: os phrasal verbs. Não obstante, as collocations, palavras que só se combinam com outras determinadas palavras, como no caso de make a cake, em vez de do a cake, recebem atenção especial na obra. Não se pode também deixar de mencionar as expressóes idiomáticas que, como a própria autora diz, “(...) nos fazem entender e ser entendidos na LE.” (p. 69) Um outro ponto essencial apontado se refere aos contrastes entre língua falada e língua escrita. Por meio de uma análise contrastiva, notamos que na língua portuguesa, basicamente se lê do jeito que se escreve, enquanto que na LI a diferença entre escrita e fala é muito maior. Há casos que uma mesma grafia possui pronúncias diferentes e significados distintos; há casos em que uma grafia distinta possua pronúncias idênticas e significados distintos. Se explicadas tais características por meio das diversas influências lexicais que a LI sofreu desde o fim do império romano do ocidente, perceberemos que a pronúncia e a semântica vivenciaram muito mais transformaçōes que a grafia. Essas transformações náo se tornaram um desafio somente para o falante estrangeiro, mas também para o falante nativo, haja vista o famoso exemplo do dramaturgo irlandês George Bernard Shaw, que em tom de brincadeira afirmava que 
fish e ghoti seriam grafias da mesma palavra $(g h-e n o u G H, o-w O m e n$, ti-naTIon), conforme vemos em Walter (1997).

$\mathrm{Na}$ parte seguinte, a autora promove um diálogo direto com o professor de LE, no tocante às formas que oralidade e fluência podem ser desenvolvidas em sala de aula, a aspectos pedagógicos, ao papel do professor no ensino da LE em um mundo em que as inovaçóes tecnológicas estáo presentes como nunca antes estiveram, e à posição do professor como agente "facilitador" de um processo de aprendizagem em que cada aluno deverá ser o protagonista. Afirma que "a fluência acontece diferentemente para cada aprendiz, [e que] cada um atingirá o conhecimento da língua a seu tempo" (p. 79) e que as atividades desenvolvidas pelo professor - em sala de aula - em busca dessa fluência - deverão estar associadas ao uso normal do idioma, contemplando as dificuldades de todos os alunos, tendo no professor o seu papel de facilitador e não mais de modelo absoluto, de protagonista.

Na parte final, intitulada "o professor de língua estrangeira", a autora traça um panorama dos desafios da profissão no universo da sala de aula brasileira. As constantes mudanças decorrentes da globalização fazem com que as posiçóes no âmbito social deixem de ser fixas e, com isso, o professor de LE também se veja em um cenário de mudanças, repleto de dinamismo, de multiperspectivas, no qual ele "deixe de ser o centro das atençóes" e passe "a intermediar a experiência e o uso linguístico de seus aprendizes." (p. I09) A autora enumera uma lista detalhada do que se espera do professor, na relaçáo com a sala de aula e com as diversas faixas etárias discentes. Posteriormente, elenca alguns aspectos que o professor deverá considerar em seu trabalho quanto às habilidades linguísticas (fala, escrita, leitura, gramática e vocabulário) e como o professor poderá integrar material didático e tecnologia de sala de aula para enriquecer a tão desafiadora tarefa de se ensinar uma LE.

Como já salientamos no início, o ensino de LE passou por diversas mudanças de métodos no decorrer da história. A autora nos faz uma breve análise dos diferentes métodos, passando pelo clássico, embasado em gramática e em tradução, até pelos mais contemporâneos, que se centram na necessidade da interaçáo social, promovida por um enfoque comunicativo, ou seja, mais importante que dominar a terminologia sintático-gramatical é o ato de se comunicar. Não sabemos quais caminhos serão tomados pelo 
ensino da LE no futuro, visto que vivemos em um presente em constante mudança, graças à globalização e ao encurtamento de distâncias entre os mais variados públicos e as mais variadas culturas. Só temos uma certeza: cada vez mais, precisaremos nos comunicar em uma LE. A autora se propôs, na obra em questão, a não impor regras ou verdades absolutas, mas sim a dialogar com o público docente de LE, dividir um pouco de sua vasta experiência com este público, por meio de uma atitude acadêmica, resultante de seus diversos anos de pesquisa, mas profundamente prática, a partir de suas próprias vivências no magistério, para que sua obra possa sugerir alguns rumos a serem seguidos pelos profissionais da área nesse belo - e desafiador - ofício que é lecionar LE. 
